\title{
Dreyfus, Hubert and Sean Dorrance Kelly, All Things Shining: Reading the Western Classics to Find Meaning in a Secular Age ${ }^{1}$
}

Tracy Ann P. Llanera

$\mathrm{T}$

he anthem of autonomy-that each man determines his own fateresonates as a boon and a curse of the secular, modern era. On the one hand, it is inspiring to imagine that every person can illuminate the purpose of his life. Modernity, after all, sings of emancipation from external and supernatural forces, and campaigns that man's capacity for critical reflection and freedom of choice can fight against the mystification of thought and action. In this post-Kantian and post-Nietzschean climate, the lesson is that there need not be room for God or even small gods; the power of humanity suffices to brighten the dark corners of the universe. The authority of tradition and the institutions of domination thus find their match in the figure of the Enlightened Man. ${ }^{2}$ On the other hand, the impressive gains of autonomy also come with magnificent losses. The tendency to portray personal choice as an imperative of every individual—an imperative that guarantees neither satisfaction nor certainty-also heightens the consciousness of isolation and responsibility. Instead of empowering, the availability of too many options and the burden of defining one's life have produced a distressing atmosphere of confusion and lostness ${ }^{3}$, as unlimited freedom appears to be too overwhelming atop the shoulders of a mere human being. This realization is worsened by the modern disbelief in the existence of powers outside us that can console in times of defeat. Looking up or beyond the means of our human agency for aid can be judged as weakness or escapism. The secular age hence displays a

\footnotetext{
${ }^{1}$ New York: Free Press, 2011. 254 pp.

2 "Enlightenment is man's emergence from his self-imposed immaturity." See Immanuel Kant's essay “An Answer to the Question: What is Enlightenment?”(1784).

${ }^{3}$ In the early $20^{\text {th }}$ century, works such as T.S. Eliot's Wasteland and Samuel Beckett's Endgame testify to the dark fate of modern lives. See Hubert and Kelly, All Things Shining, 28-29. What is important now for Dreyfus and Kelly is that we concentrate on texts that explore uplifting responses to this contemporary conundrum.
} 


\section{ALL THINGS SHINING}

pervasive distrust against the truth and comfort that a belief in God, or even in small gods, can bring to our lives. ${ }^{4}$

This picturing of modernity suggests that our perspective of the sacred these things and events that pulsate with a power outside our own skin, and are believed to bring out the best and richest sources of meaning in a particular time and place-has been lost along the Enlightenment march. But instead of surrendering to the conviction that this vision has slipped from our grasp forever, Hubert Dreyfus and Sean Dorrance Kelly contend that we can unearth crucial moments that throb with a godlike presence by reading the Western Classics. Against the sweeping mood of disorientation and meaninglessness, the book All Things Shining reorients us by attempting to recapture and vivify the sacred in the contemporary world.

The two authors heed the Heideggerian counsel that art focuses on what is important and meaningful in a specific culture. ${ }^{5}$ They follow the idea that "when works of art shine, they illuminate and glamorize a way of life, and all other things shine in their light. A work of art embodies the truth of its world." Thus, works such as Homer's Odyssey, Herman Melville's Moby Dick, and David Foster Wallace's Infinite Jest and The Pale King are plowed in this text to trace the truths latent in the hidden history of the West and explain how we have lost the glimmer of sacred. From this literary excavation that judges the accomplishments of our civilization, it then becomes possible to deftly explore if, in the secular, modern age, there remains room for great things that shine beyond the glory of human achievement.

\section{Moods and the Sacred}

In their search for the sacred, Dreyfus and Kelly lay emphasis on the notion of moods, or the attunement to what human beings consider as spiritually important in a society or a culture at different fissures in time. They explain that the Greeks in the Odyssey $\left(8^{\text {th }}\right.$ century BC), for example, believed in a polytheism that adhered to the multifarious and often conflicting ideals of human excellence. The merit and

${ }^{4}$ This does not mean that forms of religious belief have been eliminated within our midst; in fact, the world's search for spiritual meaning remains strong and serves as a living thematic for philosophers today. For example, "Taylor sees the radical proliferation of religions and spiritualitya veritable explosion of religious lives—as the central feature of the modern age." Ibid., 21.

The difference in this age, however, is the understanding that religion, or spirituality, is now simply an option. One can live without a profession of faith. As Taylor poses: "why was it virtually impossible not to believe in God in, say, 1500 in our Western society, while in 2000 many of us find this not only easy, but even inescapable?" See Charles Taylor, A Secular Age (Harvard University Press, 2007), 25.

${ }^{5}$ See Martin Heidegger, “The Origin of the Work of Art," in Poetry, Language, and Thought, trans. by A. Hofstadter (New York: Harper \& Row, 1971).

${ }^{6}$ Hubert and Kelly, All Things Shining, 102.

(C) 2012 Tracy Ann P. Llanera

http://www.kritike.org/journal/issue 11/llanera june2012.pdf

ISSN 1908-7330 
prominence of human actions back then were not sourced from a radiance within; rather, they were based on the vivacity of impersonal moods that brighten a particular moment and inspire people to act. These public moods were represented by Olympian divinities that characterize the various ways of being and acting in the world. Being attuned to what these gods stood for, and responding to their calls when they made them at particular instances, would constitute what is admirable for the inhabitants of Ancient Greece:

What makes Helen great in Homer's world is her ability to live a life that is constantly responsive to golden Aphrodite, the shining example of the sacred erotic dimension of existence. Likewise, Achilles had a special kind of receptivity to Ares and his warlike way of life; Odysseus had Athena, with her wisdom and cultural adaptability, to look out for him. Presumably, the master craftsmen of Homer's world worked in the light of Hephaestus's shining. ${ }^{7}$

In the days of Homer, then, moods were external and shareable. Regarded as the basis of public commitments and actions, men were judged according to their openness to what these gods invite them to be or to do. However, in the progression of Western literature, these public moods seem to have morphed into private states or dispositions. This line of development is recognizable upon interpreting the works of Aeschylus, the Gospel of John, Paul, Augustine, Dante, Luther, Descartes and Kant. All of them contributed to shifting the status of man from a vessel or a victim dancing to the sway of forces beyond his control, to a dignified selfconsciousness able to steer the direction of his life. This change implies that public moods, previously considered as the centering standards of human action, were eventually transformed into inner beliefs and responsibilities exclusive to every thinking and feeling subject. And this inward orientation, as Dreyfus and Kelly claim, soon found itself bound up with the confusion and lostness wafting the air of the contemporary period.

In fact, this sense of modern inwardness culminates in Wallace's masterpiece, Infinite Jest (1996), which talks about our fascination with distractions: entertainments that lead to a disinterest and detachment from life. By dangerously combining both the idea that human freedom is our generation's sacred commitment as well as the smothering moods of boredom, angst, and loneliness in one plot, the book displays the possible implosion of the individual in our age. According to Wallace, the problems setting us adrift can be overcome through a modern form of salvation: that we must, with effort and resolve, will to experience the world in a meaningful way. He warns, of course, that this is "a choice that takes

${ }^{7}$ Ibid., 62.

(C) 2012 Tracy Ann P. Llanera http://www.kritike.org/journal/issue 11/llanera june2012.pdf ISSN 1908-7330 


\section{ALL THINGS SHINING}

strength and courage and persistence, of course; perhaps it takes even a kind of heroism." Such is the modern mood: to live fully, we have to become gods ourselves. For the genius behind The Pale King, only the self is sacred. A person can shine if he is strong enough to will and master his life. This, however, happens but rarely.

Dreyfus and Kelly think that resorting to pure personal will in order to confront frustrations our own way is futile a suggestion. It only confirms the reality of human fragility, and hence appears to be self-defeating as a solution to the modern predicament. Frowning upon Wallace's nihilism, they think that perhaps looking at other possible moods, or other modern accounts of being or attuning to the world, may help address our search for meaning and salvation better. They propose that as a literary resource, Melville's Moby Dick (1851) displays better ways of coming nearer to a more enriching life. The many personages and images in this novel portray different moods that deal with things that are mysterious but may be meaningful to us. For instance, the monomaniacal Ahab-a character bent on understanding whether the great whale is a malicious animal or an unthinking brute-represents Wallace's modern mood. Through the strength of human determination, he believes that we can strike meaning and find certainty in the universe on our own. Unlike him, the narrator Ishmael is a fellow who dares take seriously the joys and failures of our many human moods. Constantly open to the changing representations that are revealed in his encounters with the uncanny Moby Dick, he stands for a kind of person who is receptive to the many forms that shining things can take. The whale itself, finally, is a being that inspires a pantheistic understanding of the world: "Sometimes the universe is meaningless, it is truesometimes a death is senseless or dumb. But the universe has its brute and reflexlike moments as well, in addition to malicious and vindictive and devilish ones. And in addition to all these, it is also gently joyous and divine." This novel, then, advocates a receptivity to things that we do not fully understand, and encourages the search for meaning in the waves of enigma and indeterminacy.

The moods found in Melville's tale thus display a mixture of an attunement to sacred things outside ourselves, and an orientation toward our own capacity or awareness to respond to them. It is not an endorsement to return to the childlike fervor of the Ancient Greeks, where control is given up in favor of external thralldom; rather, it is a fresh account of how we can evade the pitfalls of our modern temper by being receptive and conscious of the many faces that sacred, shining things can wear. Unlike Wallace, who thinks that without any help from powers beyond us we can still save our own skin, Melville seems to evoke the hope that a different disposition - one that puts together the mystery of the external world and the openness of the self - may be the appropriate mood to have in the modern age.

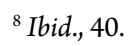

${ }^{9}$ Ibid., 185

(C) 2012 Tracy Ann P. Llanera

http://www.kritike.org/journal/issue 11/llanera june2012.pdf

ISSN 1908-7330

\section{(cc) BY-NC}




\section{The Sacred Today}

In All Things Shining, the contemporary sense of the sacred is manifested when one feels swept away or is "whooshed up" by the intensity of an event. This phenomenon happens when, in the face of something truly marvelous, one cannot deny that something heroic or superhuman has been accomplished, so much so that it moves the perceiver to awe or initiates an instinctive reaction. The favored example is the experience of sport. Whether a person plays the game or is part of the audience, there are moments when "something so overpowering happens that it wells up before you as a palpable presence and carries you along as on a powerful wave." 10

The varying examples of great contemporary moments range from men's accomplishments of good deeds (Wesley Autrey), the delivery of moving speeches (Lou Gehrig, Martin Luther King), and the display of athletic prowess (Roger Federer, Bill Bradley). It seems that these events can be described as communal, transient, and amoral. The experience of the sacred occurs in the company of a crowd: other people simultaneously feel that something extraordinary has transpired and are consequentially swept away by it. There is an undeniable acknowledgment by all that something astounding has occurred, and they are affected by its splendid nature. Also, momentary as they are, these events are temporary. They are not sustainable "highs" - they simply happen, their effects well up within one's being, and then they fade away. Hence, while our initial responses may not be directly under our control, we are left the space and time to decide what course to take next after the overwhelming situation has been blown away. Lastly, what rouses our admiration does not necessarily imply virtue. Sometimes the effect of a great moment can inspire goodness and at other times lead to ruin-e.g., Martin Luther King's speech may be considered as stirring as Adolf Hitler's fantastical rhetoric. Both were able to rally hearers to action, to both good and evil. This is the danger that falling under the spell of polytheistic forms of the sacred poses.

Dreyfus and Kelly recognize that during an ecstatic event, there occurs an uncontrollable sacrifice of reflective, critical thought. Hence, they argue that our response to shining moments should, in a sense, be trained or tempered. They call this meta - poesis: the cultivation of a skill that discerns the appropriate response to an extraordinary event. ${ }^{11}$ The leap towards both the good and the dark side must be courageously made, but what we must learn is to determine when it is appropriate to be swept up by an event that approximates the sacred if it is noble, but be able to resist its attraction and abandon it when need be if it leads to destruction. Meta-

\footnotetext{
${ }^{10}$ Ibid., 194.

${ }^{11}$ This approach is inspired by the Greek idea of poesis, or the nurturing art of understanding one's work, and bringing out the best from its performance and product. Ibid., 206 - 212.
} 


\section{ALL THINGS SHINING}

poesis stands for the idea that "living well in our secular, nihilistic age, therefore, requires the higher-order skill of recognizing when to rise up as one with the ecstatic crowd and when to turn heel and walk rapidly away." 12 This allows us to be open to experience greatness and awe, but without risking the loss of the stance of an enlightened maturity.

\section{Observations}

While this modern return to the life of the Spirit is inspiring a proposal, there are several concerns that assuredly merit a critical eye. First, the contemporary examples of sacred events-Autrey's heroism, Federer's athletic grace, Gehrig's declamation-appear to have been chosen by Dreyfus and Kelly in view of their appeal to the masses. They are presented as if they are all unique and even unprecedented in nature. But are not good acts and sporting events and inspiring speeches present in many places, and don't they occur often, in fact, even regularly? In the same vein, don't horrible crimes and violent sports find their place in our personal and communal lives as well? How come these instances do not cause us to 'whoosh up', motivating us to reach for something beyond ourselves? Does our less than ecstatic response not serve as evidence that these godlike events are neither adequate nor convincing enough to move us to inspiration and action? What if the problem, really, is that the modern indifference or insensitivity to these moments is too strong, and that we have to respond to this numbing illness first before anything else?

Second, there is good reason to further engage the question of our moral responses to ecstasy and awe. Again, shining moments proffer natural highs to satisfy the modern void in the individual-it seems that this effect is not different from the stupor that drugs and alcohol, or religious intoxication and fanaticism, can bring. The lack of control, after all, is the profound point of the experience. The lesson taught by the texts The Odyssey and Moby Dick and the speeches of M. L. King and Hitler is that one can but hope that a spectator will be ennobled to make the right choice even when swept off one's feet. The problem here is that the authors of the book do not adequately signal how we can best train or cultivate poesis to strengthen our discerning will. So we ask: will the use of the creative imagination and exposure to art and literature help? Is there a point of endorsing a sense of both personal and public moral training to aid the development of poeisis? What are the scope and limits of a possible venture into the moral imagination?

Third, the transitory nature of these sacred moments seems inadequate to satisfy the deep demands of human fulfillment. The reason why people, for example, devote themselves to religion and to art is that these human realities condense life

${ }^{12}$ Ibid., 212.

(C) 2012 Tracy Ann P. Llanera

http://www.kritike.org/journal/issue 11/llanera june2012.pdf

ISSN 1908-7330 
into a habit. The dedication to faith or to passion can often sediment into a 'vocation', a life informed by a constant way of being or appreciating the world. But how do moments of meeting the temporary sacred, as elucidated in All Things Shining, compensate or gratify this need for a life of constant fullness? The suggestions of Kelly or Dreyfus neither seem to approximate this desire for lifelong satisfaction, nor illuminate the way to cultivate a life abundant in holistic value. They merely say that men, if they reflect upon their existence well enough, may know what they are drawn toward and can thereafter follow can the path that can make them truly happy. But the problem of modernity is the confusion and lostness to what we are truly called to do remains! Indecision persists, and maybe even more so in the era of freedom and plurality.

In conclusion, the modern anthem of autonomy continues to resound significantly in the work of Dreyfus and Kelly, but this time it does so in recognition and openness to the great possibilities we can discover in this "wonderful world of sacred, shining things". There is an uplifting beauty in walking through modern life this way. But just how powerful these sacred moments are in imbuing our lives with a constant abundance of depth and meaning, we are yet bound to discover.

Department of Philosophy, Macquarie University, Australia

\section{References}

Dreyfus, Hubert and Sean Dorrance Kelly, All Things Shining: Reading the Western Classics to Find Meaning in a Secular Age (New York: Free Press, 2011). Heidegger, Martin, "The Origin of the Work of Art," in Poetry, Language, and Thought, trans. by A. Hofstadter (New York: Harper \& Row, 1971). Taylor, Charles, A Secular Age (Harvard University Press, 2007). 